\title{
Radiometric analysis of volcanic tuff stones used as ornamental and structural building materials in Turkey and evaluation of radiological risk
}

\author{
Ş. Turhan ${ }^{1 \star}$, E. Atıc1 ${ }^{2}$ and A. Varinlioğlu ${ }^{3}$ \\ ${ }^{1}$ Kastomunu University, Faculty of Science and Letters, Department of Physics 37150 Kastamonu, Turkey. \\ 2 Nevşehir University, Institute of Science, Department of Physics 50300 Nevşehir, Turkey. \\ ${ }^{3}$ Çekmece Nuclear Research and Training Centre, P.O. Box 1, 34831 Atatürk Airport Istanbul, Turkey.
}

Received 14 May 2015 - Accepted 25 August 2015

\begin{abstract}
Volcanic tuff stones are widely used to coat the interior and exterior surfaces of buildings for ornamental purposes in the construction industry in Turkey, and are also used as structural material in the construction of masonry buildings, especially in the Cappadocia region, which is a popular tourist destination. In this study, seventy-six volcanic tuff stone samples collected from different quarries located in different geographical regions in Turkey were surveyed for radiometric analysis, and the radiological risk to human health caused by ionizing radiation from natural radionuclides in the volcanic tuff stone samples was evaluated. The activity concentrations of ${ }^{238} \mathrm{U},{ }^{232} \mathrm{Th},{ }^{226} \mathrm{Ra}$ and ${ }^{40} \mathrm{~K}$ analyzed in volcanic tuff stone samples were very variable, ranging from 3 to 389,8 to 401,2 to 263 and 99 to $2107 \mathrm{~Bq} \mathrm{~kg}^{-1}$, respectively. The emanation coefficient and mass exhalation rate of ${ }^{222} \mathrm{Rn}$ measured for the volcanic tuff samples ranged from 2 to $68 \%$ with an average of $34 \%$, and 1 to $194 \mu \mathrm{Bq} \mathrm{kg}^{-1} \mathrm{~s}^{-1}$ with an average of $43 \mu \mathrm{Bq} \mathrm{kg}^{-1} \mathrm{~s}^{-1}$, respectively. The external (gamma) and internal (alpha) hazard indices, indoor absorbed gamma dose rate and the corresponding annual effective dose were estimated to evaluate the potential radiological risk to human health. The results showed that all of the surveyed volcanic tuff stone samples can be used as covering building materials for ornamental or insulating covering purposes. However, the use of some volcanic tuff stone samples as structural building materials should be restricted.
\end{abstract}

Keywords: natural radioactivity / radon mass exhalation rate / emanation coefficient / hazard indices / annual effective dose / radiological risk / volcanic tuff

\section{Introduction}

All building raw materials and products derived from rock and soil contain various amounts of naturally occurring radionuclides of the uranium-radium $\left({ }^{238} \mathrm{U}^{226} \mathrm{Ra}\right)$ and thorium $\left({ }^{232} \mathrm{Th}\right)$ series, and the radioactive isotopes of potassium $\left({ }^{40} \mathrm{~K}\right)$. Enhanced or elevated levels of natural radionuclides in building materials may cause a radiological risk to human health due to external and internal exposure (Marocchi et al., 2011). The external exposure is caused by direct gamma radiation originating from the above-mentioned members of radioactive series, while internal exposure is caused by the inhalation of the radioactive inert gas radon $\left({ }^{222} \mathrm{Rn}\right.$, a daughter product of ${ }^{226} \mathrm{Ra}$ ) and its short-lived secondary decay products, which are exhaled from building materials into room air. Knowledge of the level of natural radioactivity in building materials is therefore essential to evaluate the possible radiological hazards to human health and develop standards and guidelines for the use and management of these materials (Turhan, 2009).

\footnotetext{
* serefturhan63@gmail.com
}

Volcanic tuff stones consisting of consolidated volcanic ash, and large and small pieces ejected from vents during a volcanic eruption, with a porous structure in different colours, are used as covering materials for insulating and ornamental purposes on the exterior and interior of buildings in Turkey. Up until now, several studies on the radiometric, petrographic and mineralogical properties of natural stone samples have been reported (Anjos et al., 2005; Xinwei et al., 2006; El-Arabi, 2007; Asghar et al., 2008; Kitto et al., 2009; Koornneef et al., 2010; Lanzo et al., 2010; Moura et al., 2011; Abd El-Ghafour et al., 2012; Capaccioni et al., 2012; Trevisi et al., 2012; Turhan, 2012). However, according to our literature survey, a comprehensive study related to the radiometric properties of volcanic tuff samples collected from Turkey has not yet been conducted, except one study in which eight volcanic tuff samples were considered (Değerlier, 2013). In this study, a total of 76 volcanic tuff stones collected from different quarries located in four geographical regions of Turkey were analyzed using gamma-ray spectrometry to determine the activity concentration of ${ }^{238} \mathrm{U},{ }^{232} \mathrm{Th},{ }^{226} \mathrm{Ra}$ and ${ }^{40} \mathrm{~K}$, and the emanation 
Table 1. Information on the locations of quarries, sample codes and sample colors.

\begin{tabular}{lccc}
\hline Quarry code & $\mathbf{N}^{\circ}$ & Sample colors (number of samples) & Quarry place (geographical region) \\
\hline Q1 & 6 & Yellow (2), black (1), cherry (1), dark gray (1), dusty-rose (1) & Kayseri-Tomarza (Central Anatolia) \\
Q2 & 6 & Yellow (2), brown (1), black (1), dusty-rose (2) & Kayseri-Tomarza (Central Anatolia) \\
Q3 & 7 & Cherry (1), red (1), brown (1), yellow (1), gray (1), dusty-rose (1), black (1) & Kayseri-Tomarza (Central Anatolia) \\
Q4 & 7 & Gray (4), black (1), dusty-rose (1), brown (1) & Kayseri-Tomarza (Central Anatolia) \\
Q5 & 4 & Yellow (3), brown (1) & Kayseri-Tomarza (Central Anatolia) \\
Q6 & 6 & Yellow (1), black (1), gray (1), dusty-rose (1), fawn (1), dark brown (1) & Kayseri-Develi (Central Anatolia) \\
Q7 & 4 & Gray (4) & Kayseri-Melikgazi (Central Anatolia) \\
Q8 & 3 & Gray (2), yellow (1) & Kayseri (Central Anatolia) \\
Q9 & 6 & Yellow (1), cherry (1), black (1), white (1), red (1), turquoise (1) & Nevşehir-Ürgüp (Central Anatolia) \\
Q10 & 5 & Yellow (1), cherry (1), dusty-rose (1), light brown (1), black (1) & Nevşsehir-Avanos road (Central Anatolia) \\
Q11 & 4 & Yellow-white (1), white (1), dark yellow (1), Cappadocia rose (1) & Nevşehir-Aksaray road (Central Anatolia) \\
Q12 & 1 & Brown (1) & Nevşehir-Ürgüp (Central Anatolia) \\
Q13 & 6 & Fawn (2), dark brown (1), beige (1), brown (1), cream (1) & Isparta (Mediterranean) \\
Q14 & 6 & Beige (1), yellow (1), gray (1), cream (1), dusty-rose (1), white (1) & Afyon (Aegean) \\
Q15 & 2 & Brown (2) & Manisa (Aegean) \\
Q16 & 2 & Rose-colored (2) & Eskişehir (Central Anatolia) \\
Q17 & 1 & Maroon (1) & Diyarbakır (Southeast Anatolia) \\
\hline
\end{tabular}

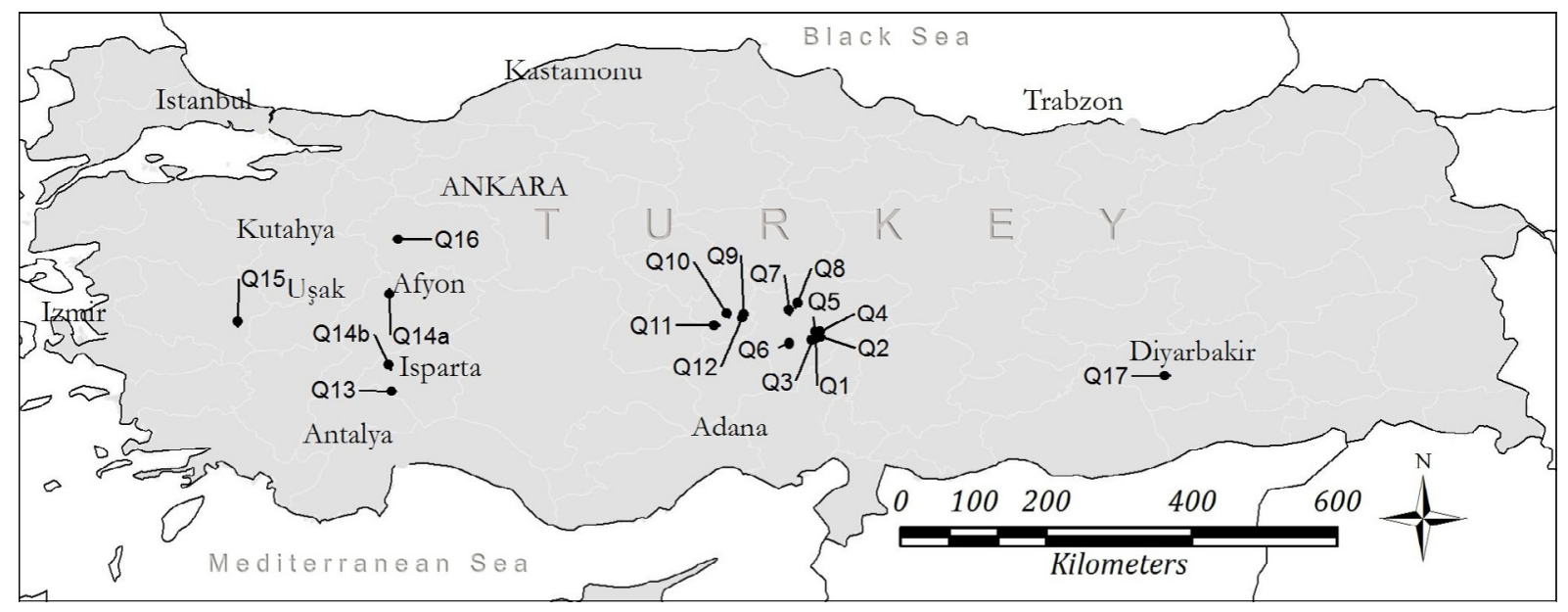

Figure 1. Map showing the volcanic tuff samples' locations.

coefficient and mass exhalation rate of ${ }^{222} \mathrm{Rn}$. The gamma index, alpha index, indoor absorbed gamma dose rate and the corresponding annual effective dose were estimated for each volcanic tuff stone to evaluate the potential radiological risk to members of the public, spending most of their time indoors. The results obtained in this study were compared with the upper or reference values recommended or proposed by the World Health Organization (WHO), United Nations Scientific Committee on the Effects of Atomic Radiation (UNSCEAR) and European Commission (EC).

\section{Materials and method}

\subsection{Sampling and sample preparation}

Volcanic tuff stone samples were collected from different quarries located in Central Anatolia, Eastern Anatolia, and
Mediterranean and Aegean regions in Turkey, catalogued and coded properly (Table 1). The sampling locations in the study areas are shown in Figure 1. The samples were crushed, pulverized and then dried in a temperature-controlled furnace at $105^{\circ} \mathrm{C}$ for $24 \mathrm{~h}$ to remove moisture. After moisture removal, these samples were cooled in a moisture-free atmosphere. Each sample was transferred to a 1-L Marinelli container and weighed. Sample containers were hermetically sealed and allowed to stand for at least four weeks to ensure short-term equilibrium between ${ }^{226} \mathrm{Ra}$ and its short-lived decay products.

\subsection{Measurement system for radiometric analysis}

Radiometric analyses were performed using a gamma-ray detection system with a high-resolution coaxial p-type horizontal HPGe detector (Canberra GX3018). The resolution of the detector is $1.8 \mathrm{keV}$ for ${ }^{60} \mathrm{Co}$ gamma-ray line energy at $1332.5 \mathrm{keV}$ and it has a relative efficiency of $30 \%$. The detector 
was shielded to minimize natural background radiation from the environment. The certificated standard calibration source of a 1-L Marinelli beaker which contains multinuclides distributed in $1.0 \mathrm{~g} \mathrm{~cm}^{-3}$ epoxy (Eckert \& Ziegler Isotope Products) was used for efficient calibration of the system in the energy range from $122 \mathrm{keV}$ to $1836 \mathrm{keV}$. The counting time for each sample was adjusted to obtain a gamma-ray spectrum with good statistics. The activity concentration of ${ }^{238} \mathrm{U}$ was derived from the weighted average of the gamma-ray lines of $63.3 \mathrm{keV}$ and $92.3 \mathrm{keV}$ of ${ }^{234} \mathrm{Th}$ corrected for selfadsorption effects. The activity concentration of ${ }^{40} \mathrm{~K}$ was measured directly by its own gamma ray at $1460.8 \mathrm{keV}$, while the activities of ${ }^{226} \mathrm{Ra}$ and ${ }^{232} \mathrm{Th}$ were calculated based on the weighted mean value of their respective decay products in secular equilibrium. The activity concentration of ${ }^{226} \mathrm{Ra}$ was measured using the $351.9 \mathrm{keV}$ gamma-ray line from ${ }^{214} \mathrm{~Pb}$ and the $609.3 \mathrm{keV}$ gamma-ray line from ${ }^{214} \mathrm{Bi}$. The activity concentration of ${ }^{232} \mathrm{Th}$ was measured using the $911.2 \mathrm{keV}$ gamma-ray line from ${ }^{228} \mathrm{Ac}$ and the $583.2 \mathrm{keV}$ gamma-ray line from ${ }^{208} \mathrm{Tl}$. The lower limit of detection $\left(\mathrm{L}_{\mathrm{D}}\right)$ of the gamma-ray spectrometer with a $95 \%$ confidence limit was estimated using the following formula (Currie, 1968):

$$
\mathrm{L}_{\mathrm{D}}\left(\mathrm{Bq} \mathrm{kg}^{-1}\right)=\frac{1.64 \times \sigma_{\mathrm{B}}}{\varepsilon_{\gamma} \times \mathrm{I}_{\gamma} \times \mathrm{t} \times \mathrm{M}}
$$

where $\sigma_{B}$ is the standard deviation of the background in the region of interest of the gamma photopeak, $\varepsilon_{\gamma}$ is the absolute efficiency of the system, $\mathrm{I}_{\gamma}$ is the gamma-ray probability per decay, $\mathrm{t}$ is the counting time and $\mathrm{M}$ is the mass of the sample. The average values of the $\mathrm{L}_{\mathrm{D}}$ for ${ }^{238} \mathrm{U},{ }^{232} \mathrm{Th},{ }^{226} \mathrm{Ra}$ and ${ }^{40} \mathrm{~K}$ in volcanic tuff stone samples were found to be $0.8,1.2,0.9$ and 7.7 $\mathrm{Bq} \mathrm{kg}^{-1}$, respectively.

The correction for the contribution of ${ }^{232} \mathrm{Th}$ via its daughter nuclide ${ }^{228}$ Ac (1459.2 keV peak) to the $1460.8 \mathrm{keV}$ peaks of ${ }^{40} \mathrm{~K}$ was made as follows (Lavi et al., 2004):

$$
\text { Errorin } \mathrm{K} \text { activity }(\%)=9.3 \times \frac{\mathrm{A}_{\mathrm{Th}}}{\mathrm{A}_{\mathrm{K}}}
$$

where $A_{T h}$ and $A_{K}$ are the activity concentration of ${ }^{232} \mathrm{Th}$ and ${ }^{40} \mathrm{~K}$, respectively, in $\mathrm{Bq} \mathrm{kg}^{-1}$.

\section{Results and discussion}

\subsection{Radiometric analysis}

Table 2 reports the range and average values of the activity concentration of ${ }^{238} \mathrm{U},{ }^{232} \mathrm{Th},{ }^{226} \mathrm{Ra}$ and ${ }^{40} \mathrm{~K}$ measured in the volcanic tuff samples together with the statistical uncertainty, which was estimated by taking into consideration the systematic uncertainties in the efficiency calibration and counting statistical uncertainty. Skewness and kurtosis values and some statistical data of the activity concentrations of ${ }^{238} \mathrm{U}$, ${ }^{232} \mathrm{Th},{ }^{226} \mathrm{Ra}$ and ${ }^{40} \mathrm{~K}$ for all the samples are given in Table 3. As can be seen in Table 2, the highest values of the activity concentration of ${ }^{238} \mathrm{U},{ }^{232} \mathrm{Th},{ }^{226} \mathrm{Ra}$ and ${ }^{40} \mathrm{~K}$ are $389(\mathrm{Q} 13)$, 401 (Q13), 263 (Q13) and 2107 (Q5) Bq kg-1, respectively, while the lowest values of the activity concentration of the same radionuclides are $3(\mathrm{Q} 1), 8(\mathrm{Q} 1), 2$ (Q1) and $99(\mathrm{Q} 1)$ $\mathrm{Bq} \mathrm{kg}{ }^{-1}$, respectively. The average activity concentrations of ${ }^{238} \mathrm{U},{ }^{232} \mathrm{Th},{ }^{226} \mathrm{Ra}$ and ${ }^{40} \mathrm{~K}$ were found to be $94,104,62$ and $623 \mathrm{~Bq} \mathrm{~kg}^{-1}$, respectively. As can be seen in Table 3 , the values of skewness and kurtosis are significantly higher than the null value. This situation signifies the non-existence of a normal situation for the radionuclides. This is also verified by the lognormal distribution shown in Figures $2 \mathrm{a}-2 \mathrm{~d}$. It is observed in Figure 2 that the ranges of $40-100 \mathrm{~Bq} \mathrm{~kg}^{-1}, 40-120 \mathrm{~Bq} \mathrm{~kg}^{-1}$, $20-90 \mathrm{~Bq} \mathrm{~kg}^{-1}$ and $240-560 \mathrm{~Bq} \mathrm{~kg}^{-1}$ measured in tuff stone samples for ${ }^{238} \mathrm{U},{ }^{232} \mathrm{Th},{ }^{226} \mathrm{Ra}$ and ${ }^{40} \mathrm{~K}$ include $71 \%$, 68\%, $74 \%$ and $54 \%$ of the samples, respectively. The average values of these radionuclides are significantly higher than the corresponding earth crust average values, which are $33,45,32$ and $412 \mathrm{~Bq} \mathrm{~kg}^{-1}$ for ${ }^{238} \mathrm{U},{ }^{232} \mathrm{Th},{ }^{226} \mathrm{Ra}$ and ${ }^{40} \mathrm{~K}$, respectively (UNSCEAR, 2008). The typical concentration values of ${ }^{226} \mathrm{Ra}$, ${ }^{232} \mathrm{Th}$ and ${ }^{40} \mathrm{~K}$ in natural building stones utilized in European Union (EU) countries were given as 60, 60 and $640 \mathrm{~Bq} \mathrm{~kg}^{-1}$, respectively (EC, 1999). The average activity concentrations of ${ }^{226} \mathrm{Ra}$ and ${ }^{40} \mathrm{~K}$ are close to the corresponding EU quoted values, while the average activity concentration of ${ }^{232} \mathrm{Th}$ is about two times higher than the EU quoted value. Table 4 presents a comparison of the activity concentrations of ${ }^{226} \mathrm{Ra}$, ${ }^{232} \mathrm{Th}$ and ${ }^{40} \mathrm{~K}$ measured in this study for the volcanic tuff samples examined with those obtained for natural stone samples in other countries. As can be seen in Table 4, the values of the activity concentration of ${ }^{226} \mathrm{Ra},{ }^{232} \mathrm{Th}$ and ${ }^{40} \mathrm{~K}$ obtained for the volcanic tuff samples are comparable with those obtained for different natural stone samples from other studies. As can be seen in Table 2 , the average activity concentrations of ${ }^{238} \mathrm{U}$ measured in the samples from 17 quarries are higher than the earth crust's average value, while the average activity concentrations of ${ }^{232} \mathrm{Th},{ }^{226} \mathrm{R}$ and ${ }^{40} \mathrm{~K}$ measured in the samples from Q7, Q15 and Q17, Q7, Q10, Q11 and Q15, and Q1, Q7, Q11, Q15 and Q17, respectively, are lower than the earth crust's average value.

The activity concentration of ${ }^{238} \mathrm{U},{ }^{232} \mathrm{Th}$ and ${ }^{40} \mathrm{~K}$ can be converted into the elemental concentrations of $\mathrm{U}$ (in $\mathrm{mg} \mathrm{kg}^{-1}$ ), $\mathrm{Th}$ (in $\mathrm{mg} \mathrm{kg}^{-1}$ ) and $\mathrm{K}$ (in percent) using the following formula:

$$
\mathrm{C}_{\mathrm{E}}=\frac{\mathrm{A}_{\mathrm{E}} \times \mathrm{M}_{\mathrm{E}} \times \mathrm{F}}{\lambda_{\mathrm{E}} \times \mathrm{N}_{\mathrm{Av}} \times \mathrm{h}_{\mathrm{E}}}
$$

where $C_{E}$ is the elemental concentration of element $E$. $A_{E}$, $\mathrm{M}_{\mathrm{E}}, \lambda_{\mathrm{E}}, \mathrm{N}_{\mathrm{Av}}$ and $\mathrm{h}_{\mathrm{E}}$ are the measured activity concentration $\left(\mathrm{Bq} \mathrm{kg}{ }^{-1}\right)$, the atomic mass $\left(\mathrm{kg} \mathrm{mol}^{-1}\right)$, the decay constant $\left(\mathrm{s}^{-1}\right)$, Avogadro's number $\left(6.023 \times 10^{23}\right.$ atoms $\left.\mathrm{mol}^{-1}\right)$ and the atomic abundance in nature, respectively. $\mathrm{F}$ is a factor with a value of $1,000,000$ for ${ }^{238} \mathrm{U}$ and ${ }^{232} \mathrm{Th}$ in $\mathrm{mg} \mathrm{kg}^{-1}$ and 100 for ${ }^{40} \mathrm{~K}$ in percentage. The elemental concentration of ${ }^{238} \mathrm{U}$, ${ }^{232} \mathrm{Th}$ and ${ }^{40} \mathrm{~K}$ calculated for the tuff samples ranged from 0.2 to $31.5 \mathrm{mg} \mathrm{kg}^{-1}$ with an average of $17.6 \pm 0.9 \mathrm{mg} \mathrm{kg}^{-1}, 2.1$ to $98.8 \mathrm{mg} \mathrm{kg}^{-1}$ with an average of $25.6 \pm 2.5 \mathrm{mg} \mathrm{kg}^{-1}$, and from 0.3 to $7.0 \%$ with an average of $2.1 \pm 0.2 \%$, respectively. The concentrations of ${ }^{232} \mathrm{Th}$ and ${ }^{238} \mathrm{U}$ in the tuff samples were positively correlated $(\mathrm{R}=0.81)$, while ${ }^{40} \mathrm{~K}$ was weakly correlated with both ${ }^{238} \mathrm{U}$ and ${ }^{232} \mathrm{Th}$ concentrations $(\mathrm{R}=0.52$ and $\mathrm{R}=0.52$, respectively), as shown in Figure 3 . 
Table 2. The range and average value of the activity concentration of ${ }^{238} \mathrm{U},{ }^{232} \mathrm{Th},{ }^{226} \mathrm{Ra}$ and ${ }^{40} \mathrm{~K}$ measured in the volcanic tuff samples.

\begin{tabular}{|c|c|c|c|c|c|c|}
\hline \multirow{2}{*}{ Quarry code } & \multirow{2}{*}{$\mathbf{N}$} & & \multicolumn{4}{|c|}{ Activity concentration (in $\mathrm{Bq} \mathrm{kg}^{-1} \pm 1 \sigma$ ) } \\
\hline & & & ${ }^{238} \mathrm{U}$ & ${ }^{232} \mathrm{Th}$ & ${ }^{226} \mathrm{Ra}$ & ${ }^{40} \mathrm{~K}$ \\
\hline \multirow[t]{2}{*}{ Q1 } & 6 & Range & $3 \pm 1-77 \pm 3$ & $8 \pm 1-103 \pm 3$ & $2 \pm 1-68 \pm 2$ & $99 \pm 8-689 \pm 54$ \\
\hline & & Average $\pm \mathrm{SE}$ & $45 \pm 11$ & $61 \pm 14$ & $38 \pm 10$ & $395 \pm 80$ \\
\hline \multirow[t]{2}{*}{ Q2 } & 6 & Range & $36 \pm 1-117 \pm 4$ & $51 \pm 2-105 \pm 4$ & $23 \pm 1-81 \pm 3$ & $255 \pm 20-894 \pm 70$ \\
\hline & & Average $\pm \mathrm{SE}$ & $63 \pm 13$ & $67 \pm 10$ & $40 \pm 9$ & $445 \pm 95$ \\
\hline \multirow[t]{2}{*}{ Q3 } & 7 & Range & $40 \pm 1-74 \pm 3$ & $44 \pm 2-105 \pm 4$ & $25 \pm 1-61 \pm 2$ & $316 \pm 25-954 \pm 74$ \\
\hline & & Average $\pm \mathrm{SE}$ & $58 \pm 5$ & $69 \pm 8$ & $40 \pm 5$ & $574 \pm 86$ \\
\hline \multirow[t]{2}{*}{ Q4 } & 7 & Range & $26 \pm 1-89 \pm 3$ & $34 \pm 1-112 \pm 4.0$ & $23 \pm 1-89 \pm 3$ & $201 \pm 16-872 \pm 68$ \\
\hline & & Average $\pm \mathrm{SE}$ & $48 \pm 10$ & $62 \pm 12$ & $42 \pm 10$ & $415 \pm 100$ \\
\hline \multirow[t]{2}{*}{ Q5 } & 4 & Range & $130 \pm 5-182 \pm 5$ & $93 \pm 3-231 \pm 8$ & $67 \pm-117 \pm 4$ & $385 \pm 30-2107 \pm 164$ \\
\hline & & Average $\pm \mathrm{SE}$ & $149 \pm 11$ & $150 \pm 32$ & $92 \pm 11$ & $1457 \pm 382$ \\
\hline \multirow[t]{2}{*}{ Q6 } & 6 & Range & $38 \pm 1-61 \pm 2$ & $51 \pm 2-233 \pm 8$ & $36 \pm 1-53 \pm 2$ & $388 \pm 30-693 \pm 54$ \\
\hline & & Average $\pm \mathrm{SE}$ & $49 \pm 4$ & $99 \pm 28$ & $45 \pm 3$ & $506 \pm 44$ \\
\hline \multirow[t]{2}{*}{ Q7 } & 4 & Range & $26 \pm 1-73 \pm 3$ & $14 \pm 1-84 \pm 3$ & $8 \pm 1-40 \pm 1$ & $137 \pm 11-489 \pm 38$ \\
\hline & & Average $\pm \mathrm{SE}$ & $40 \pm 11$ & $34 \pm 17$ & $19 \pm 7$ & $268 \pm 83$ \\
\hline \multirow[t]{2}{*}{ Q8 } & 3 & Range & $64 \pm 2-71 \pm 3$ & $87 \pm 3-91 \pm 3$ & $38 \pm 1-55 \pm 2$ & $454 \pm 35-534 \pm 42$ \\
\hline & & Average $\pm \mathrm{SE}$ & $68 \pm 2$ & $90 \pm 1$ & $47 \pm 5$ & $491 \pm 23$ \\
\hline \multirow[t]{2}{*}{ Q9 } & 6 & Range & $46 \pm 2-77 \pm 3$ & $47 \pm 2-92 \pm 3$ & $23 \pm 1-61 \pm 2$ & $385 \pm 30-604 \pm 47$ \\
\hline & & Average $\pm \mathrm{SE}$ & $56 \pm 5$ & $70 \pm 7$ & $41 \pm 6$ & $461 \pm 37$ \\
\hline \multirow[t]{2}{*}{ Q10 } & 5 & Range & $24 \pm 1-67 \pm 2$ & $71 \pm 3-76 \pm 3$ & $15 \pm 1-41 \pm 1$ & $391 \pm 31-733 \pm 57$ \\
\hline & & Average $\pm \mathrm{SE}$ & $41 \pm 8$ & $74 \pm 1$ & $25 \pm 5$ & $515 \pm 60$ \\
\hline \multirow[t]{2}{*}{ Q11 } & 4 & Range & $36 \pm 1-49 \pm 2$ & $69 \pm 2-80 \pm 3$ & $20 \pm 1-41 \pm 1$ & $120 \pm 10-428 \pm 33$ \\
\hline & & Average $\pm \mathrm{SE}$ & $44 \pm 3$ & $75 \pm 2$ & $30 \pm 5$ & $263 \pm 67$ \\
\hline Q12 & 1 & & $103 \pm 4$ & $108 \pm 4$ & $89 \pm 3$ & $1127 \pm 88$ \\
\hline \multirow[t]{2}{*}{ Q13 } & 6 & Range & $285 \pm 10-389 \pm 14$ & $306 \pm 11-401 \pm 14$ & $137 \pm 4-263 \pm 8$ & $1086 \pm 85-1458 \pm 114$ \\
\hline & & Average \pm SE & $346 \pm 16$ & $366 \pm 15$ & $197 \pm 18$ & $1290 \pm 58$ \\
\hline \multirow[t]{2}{*}{ Q14 } & 6 & Range & $126 \pm 4-292 \pm 10$ & $1238 \pm 4-194 \pm 7$ & $111 \pm 4-23 \pm 7$ & $486 \pm 38-1245 \pm 97$ \\
\hline & & Average $\pm S E$ & $211 \pm 27$ & $159 \pm 10$ & $146 \pm 24$ & $940 \pm 122$ \\
\hline \multirow[t]{2}{*}{ Q15 } & 2 & Range & $57 \pm 2-60 \pm 2$ & $27 \pm 1-28 \pm 1.1$ & $10 \pm 1-12 \pm 1$ & $257 \pm 20-305 \pm 24$ \\
\hline & & Average $\pm \mathrm{SE}$ & $58 \pm 1$ & $28 \pm 1$ & $11 \pm 1$ & $281 \pm 24$ \\
\hline \multirow[t]{2}{*}{ Q16 } & 2 & Range & $75 \pm 3-129 \pm 5$ & $87 \pm 3-89 \pm 3$ & $27 \pm 1-108 \pm 3$ & $1147 \pm 89-1234 \pm 97$ \\
\hline & & Average \pm SE & $102 \pm 27$ & $88 \pm 1$ & $67 \pm 41$ & $1193 \pm 46$ \\
\hline Q17 & 1 & & $48 \pm 2$ & $17 \pm 1$ & $40 \pm 1$ & $102 \pm 8$ \\
\hline
\end{tabular}

Table 3. Statistical data of ${ }^{238} \mathrm{U},{ }^{232} \mathrm{Th},{ }^{226} \mathrm{Ra}$ and ${ }^{40} \mathrm{~K}$ measured in all volcanic tuff samples.

\begin{tabular}{lcccc}
\hline & ${ }^{{ }^{238} \mathbf{U}}$ & ${ }^{232} \mathbf{T h}$ & ${ }^{{ }^{226} \mathbf{R a}}$ & ${ }^{40} \mathbf{K}$ \\
\hline Average & 94 & 104 & 62 & 623 \\
$\begin{array}{l}\text { Standard } \\
\text { deviation (SD) }\end{array}$ & 92 & 90 & 57 & 424 \\
$\begin{array}{l}\text { Standard } \\
\text { error (SE) }\end{array}$ & 11 & 10 & 7 & 49 \\
Median & 59 & 79 & 40 & 471 \\
Min & 3 & 8 & 2 & 99 \\
Max & 389 & 401 & 263 & 2107 \\
$\begin{array}{l}\text { Skewness } \\
\text { Kurtosis }\end{array}$ & 2.0 & 2.1 & 1.9 & 1.4 \\
$\begin{array}{l}\text { Number } \\
\text { of samples }\end{array}$ & 76 & 4.1 & 3.1 & 1.6 \\
$\begin{array}{l}\text { Frequency } \\
\text { distribution }\end{array}$ & Log-normal Log-normal Log-normal Log-normal \\
\hline
\end{tabular}

\subsubsection{Emanation coefficient and mass exhalation rate}

The fraction of radon that can diffuse through building materials is known as the emanation coefficient $\left(\mathrm{EC}_{\mathrm{Rn}}\right)$. The $\mathrm{EC}_{\mathrm{Rn}}$ was determined using the following formula (White and Rood, 2001; Turhan and Gündüz, 2008):

$$
\mathrm{EC}_{\mathrm{Rn}}=\frac{\mathrm{CR}}{\mathrm{CR}_{\mathrm{o}}+\mathrm{CR}}
$$

where $\mathrm{CR}_{0}$ and $\mathrm{CR}$ are the net count rate of radon at the sealing time of the sample and after equilibrium (after 4 weeks), respectively. The radon mass exhalation rate $\left(\mathrm{EX}_{\mathrm{Rn}}\right)$ is the product of the emanation coefficient and ${ }^{222} \mathrm{Rn}$ production rate (Chowdhury et al., 1998). The $\mathrm{EX}_{\mathrm{Rn}}\left(\right.$ in $\mathrm{Bq} \mathrm{kg}^{-1} \mathrm{~s}^{-1}$ ) was determined by the following equation:

$$
\mathrm{EX}_{\mathrm{Rn}}=\mathrm{EC}_{\mathrm{Rn}} \times \mathrm{A}_{\mathrm{Ra}} \times \lambda_{\mathrm{Rn}}
$$

where $\mathrm{EC}_{\mathrm{Rn}}$ is the emanation coefficient given in equation (4), $\mathrm{A}_{\mathrm{Ra}}$ is the activity concentration of ${ }^{226} \mathrm{Ra}$ (in $\mathrm{Bq} \mathrm{kg}^{-1}$ ) and $\lambda_{\mathrm{Rn}}$ is the decay constant of ${ }^{222} \mathrm{Rn}\left(2.1 \times 10^{-6} \mathrm{~s}^{-1}\right)$. The average 


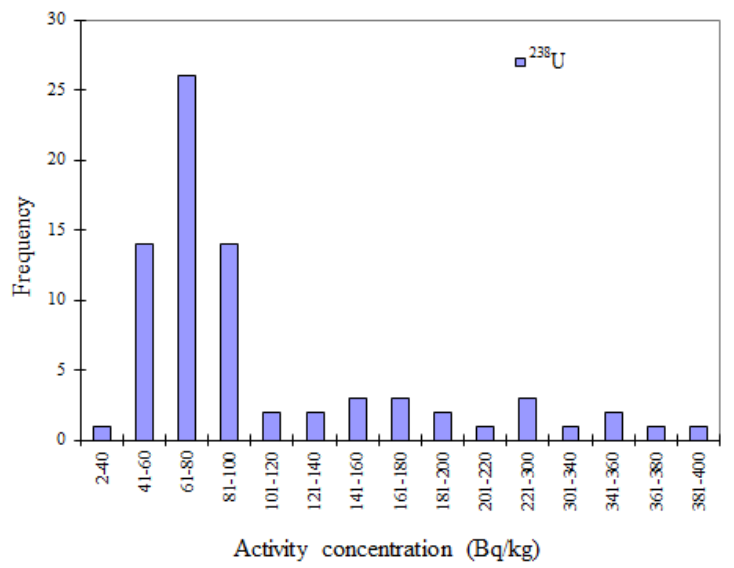

(a)

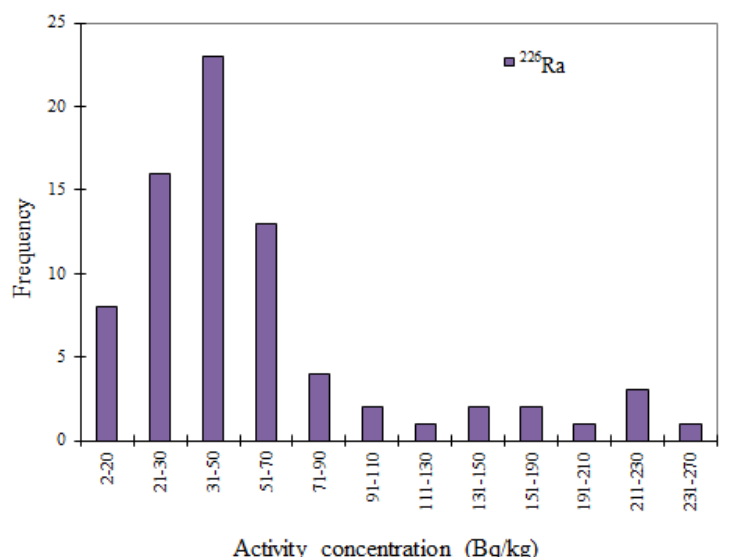

(c)

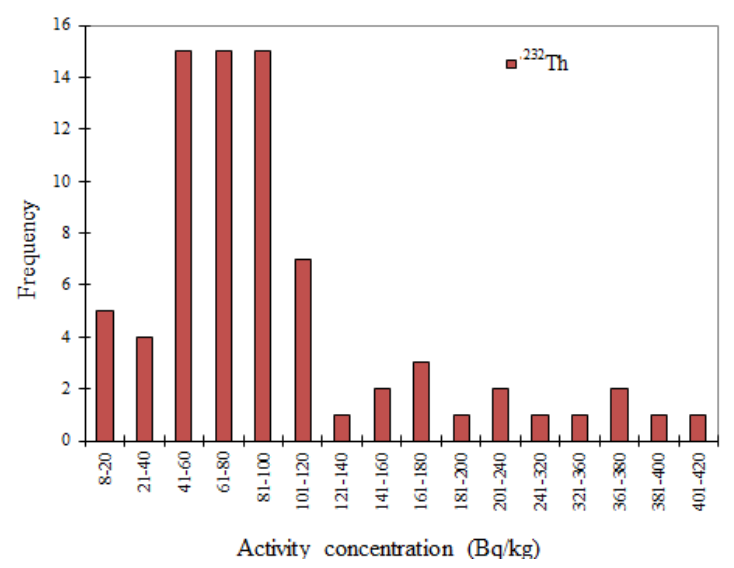

(b)

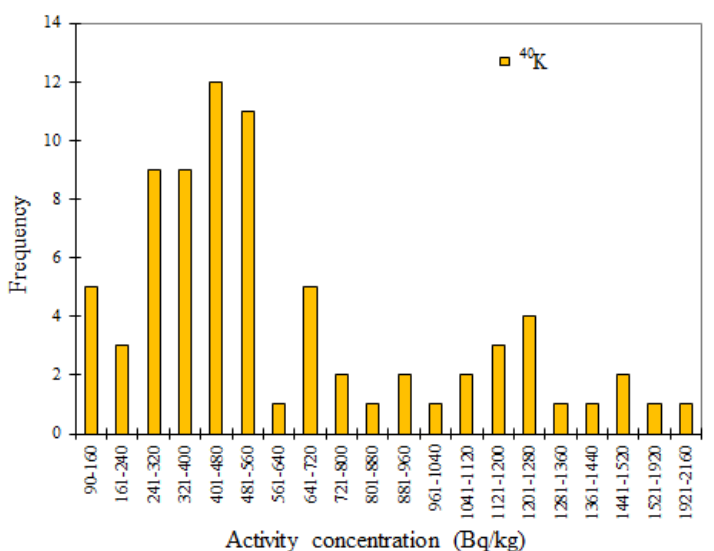

(d)

Figure 2. Frequency (number of observations) distribution of the activity concentration of ${ }^{238} \mathrm{U}$ (a), ${ }^{232} \mathrm{Th}(\mathrm{b})$, ${ }^{226} \mathrm{Ra}(\mathrm{c})$ and ${ }^{40} \mathrm{~K}(\mathrm{~d})$ in the volcanic tuff samples.

Table 4. Comparison of the activity concentrations measured in the present study for the samples examined with those obtained in other countries.

\begin{tabular}{|c|c|c|c|c|c|c|}
\hline & \multirow{2}{*}{$\mathbf{N}^{\circ}$} & \multirow{2}{*}{ Country } & \multicolumn{3}{|c|}{ Activity concentration $\left(\mathrm{Bq} \mathrm{kg}{ }^{-1}\right)$} & \multirow{2}{*}{ References } \\
\hline & & & ${ }^{226} \mathbf{R a}$ & ${ }^{232} \mathrm{Th}$ & ${ }^{40} \mathrm{~K}$ & \\
\hline Volcanic tuff & 3 & Italy & $92-280$ & $137-270$ & $1200-1900$ & Righi and Bruzzi, 2006 \\
\hline Volcanic tuff & 8 & Turkey (Kayseri) & $18-97$ & $17-96$ & $229-1036$ & Değerlier, 2013 \\
\hline Volcanic & 22 & Italy (Vulsini) & $80-394$ & $126-487$ & $227-2487$ & Capaccioni et al., 2012 \\
\hline Volcanic tuff & 76 & Turkey & $2-263$ & $8-401$ & $99-2107$ & This study \\
\hline Ornamental stone & 20 & Spain & $12-390$ & $20-490$ & $240-2000$ & Marocchi et al., 2011 \\
\hline Igneous plutonic & 387 & EU & $0.8-588$ & $0.3-906$ & $24-2040$ & Trevisi et al., 2012 \\
\hline Igneous volcanic & 86 & EU & $16-709$ & $8-750$ & $170-2354$ & Trevisi et al., 2012 \\
\hline Granite & 42 & Turkey & 9-193 & $8-345$ & $92-4156$ & Turhan, 2012 \\
\hline
\end{tabular}

values of the emanation coefficient and the ${ }^{222} \mathrm{Rn}$ mass exhalation rate of the volcanic tuff samples investigated in this study ranged from $2 \%$ to $68 \%$ with an average of $34 \%$, and 1 to $194 \mu \mathrm{Bq} \mathrm{kg}^{-1} \mathrm{~s}^{-1}$ with an average of $43 \pm 5 \mu \mathrm{Bq} \mathrm{kg}^{-1} \mathrm{~s}^{-1}$, respectively.

\subsection{Evaluation of radiological risk}

In this study, the external (gamma) and internal (alpha) hazard indices, indoor absorbed gamma dose rate and the corresponding annual effective dose were estimated for each volcanic tuff sample to evaluate the radiological risk to health associated with usage of the samples as structural and ornamental building materials in Turkey.

\subsubsection{Gamma index}

A number of indices dealing with the evaluation of the excess gamma radiation originating from building materials 


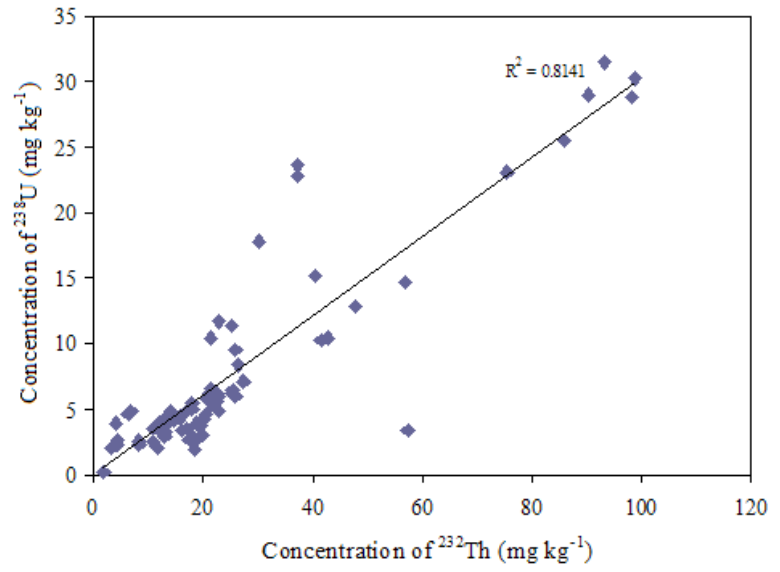

(a)

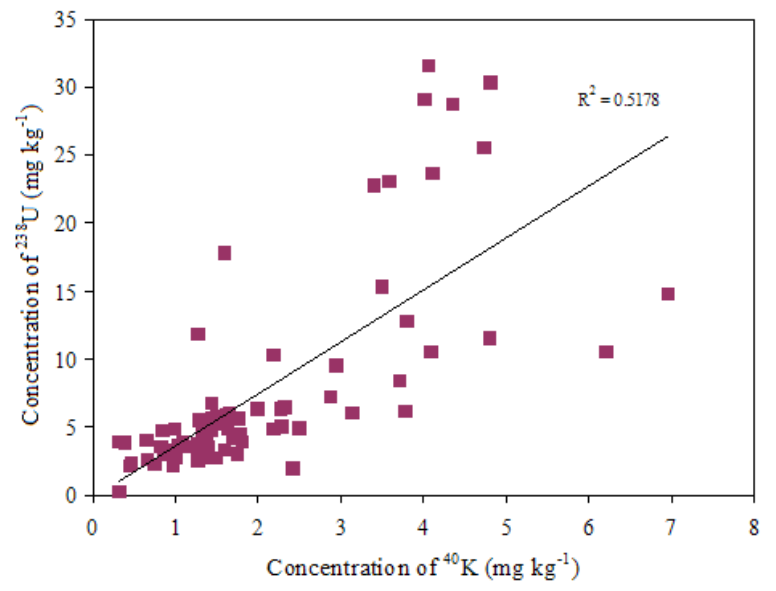

(b)

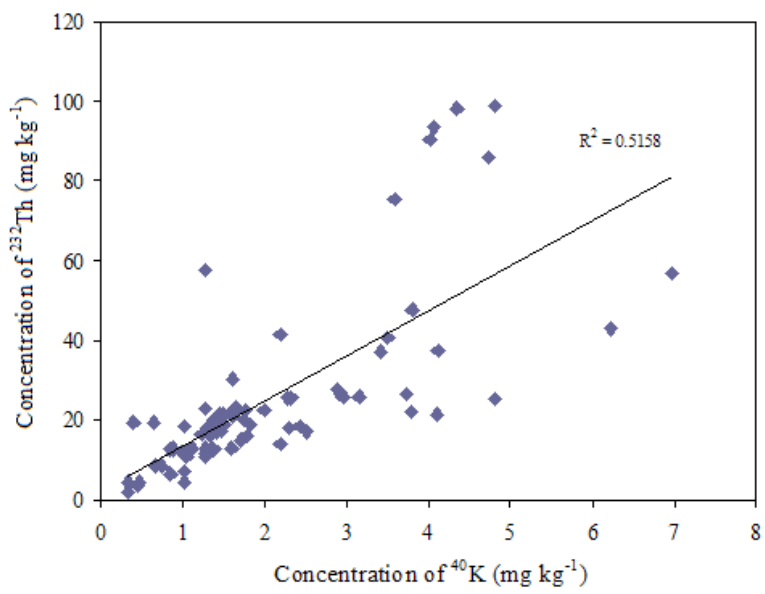

(c)

Figure 3. Correlations between ${ }^{232} \mathrm{Th}^{238} \mathrm{U}$ (a), ${ }^{40} \mathrm{~K}-{ }^{238} \mathrm{U}$ (b) and ${ }^{40} \mathrm{~K}-{ }^{232} \mathrm{Th}(\mathrm{c})$ in the volcanic tuff samples.

were proposed by several authors (EC, 1999). In this study, the gamma index $\left(\mathrm{I}_{\gamma}\right)$ proposed by the European Commission was estimated to evaluate external gamma radiation exposure caused by radionuclides in the volcanic tuff samples. In EU member countries, building materials should be exempted from all restrictions concerning their radioactivity if the excess gamma radiation originating from them increases the annual effective dose of a member of the public by $0.3 \mathrm{mSv}$ at
Table 5. The average values of the gamma index $\left(\mathrm{I}_{\gamma}\right)$, alpha index $\left(\mathrm{I}_{\alpha}\right)$, indoor absorbed gamma dose rate $\left(\mathrm{D}_{\text {in }}\right)$ and the corresponding annual effective dose $\left(\mathrm{E}_{\mathrm{in}}\right)$.

\begin{tabular}{lcccc}
\hline Quarry code & $\mathbf{I}_{\gamma}$ & $\mathbf{I}_{\alpha}$ & $\mathbf{D}_{\text {in }}\left(\mathbf{n G y ~ \mathbf { h } ^ { - 1 }}\right)$ & $\mathbf{E}_{\text {in }}(\mathbf{m S v})$ \\
\hline Q1 & 0.56 & 0.19 & 133 & 0.6 \\
Q2 & 0.61 & 0.20 & 146 & 0.7 \\
Q3 & 0.67 & 0.20 & 158 & 0.8 \\
Q4 & 0.59 & 0.21 & 140 & 0.7 \\
Q5 & 1.54 & 0.46 & 366 & 1.8 \\
Q6 & 0.81 & 0.23 & 191 & 0.9 \\
Q7 & 0.32 & 0.10 & 76 & 0.4 \\
Q8 & 0.77 & 0.23 & 181 & 0.9 \\
Q9 & 0.64 & 0.21 & 152 & 0.7 \\
Q10 & 0.62 & 0.12 & 145 & 0.7 \\
Q11 & 0.57 & 0.15 & 132 & 0.6 \\
Q12 & 1.21 & 0.45 & 291 & 1.4 \\
Q13 & 2.92 & 0.98 & 687 & 3.3 \\
Q14 & 1.59 & 0.73 & 384 & 1.9 \\
Q15 & 0.27 & 0.06 & 63 & 0.3 \\
Q16 & 1.06 & 0.34 & 254 & 1.2 \\
Q17 & 0.25 & 0.20 & 64 & 0.3 \\
\hline
\end{tabular}

most (EC, 1999). The criterion for controlling building materials should be established considering the overall circumstances of each nation; it is also recommended that controls should be based on an annual effective dose in the range $0.3-1 \mathrm{mSv}$. $\mathrm{I}_{\gamma}$ was estimated for building materials using the following formula (EC, 1999):

$$
\mathrm{I}_{\gamma}=\frac{\mathrm{A}_{\mathrm{Ra}}}{300 \mathrm{~Bq} \mathrm{~kg}^{-1}}+\frac{\mathrm{A}_{\mathrm{Th}}}{200 \mathrm{~Bq} \mathrm{~kg}^{-1}}+\frac{\mathrm{A}_{\mathrm{K}}}{3000 \mathrm{~Bq} \mathrm{~kg}^{-1}}
$$

where $A_{R a}, A_{T h}$ and $A_{K}$ are the activity concentrations of ${ }^{226} \mathrm{Ra},{ }^{232} \mathrm{Th}$ and ${ }^{40} \mathrm{~K}$ in terms of $\mathrm{Bq} \mathrm{kg}{ }^{-1}$, respectively. For structural materials used in bulk amounts, $\mathrm{I}_{\gamma} \leqslant 1$ corresponds to an annual effective dose less than or equal to $1 \mathrm{mSv}$, while $\mathrm{I}_{\gamma} \leqslant 0.5$ corresponds to an annual effective less than or equal to $0.3 \mathrm{mSv}$. For superficial materials, $\mathrm{I}_{\gamma} \leqslant 6$ corresponds to an annual effective dose less than or equal to $1 \mathrm{mSv}$, while $\mathrm{I}_{\gamma} \leqslant 2$ corresponds to an annual effective dose less than or equal to $0.3 \mathrm{mSv}(\mathrm{EC}, 1999)$. The estimated $\mathrm{I}_{\gamma}$ for all volcanic tuff samples ranged from 0.1 to 3.4 with an average of $0.9 \pm$ 0.1 . The average values of $\mathrm{I}_{\gamma}$ are given in the second column of Table 5. It can be seen in Table 5 that the highest values of the $\mathrm{I}_{\gamma}$ estimated for the volcanic tuff samples are 2.9 (Q13), $1.6(\mathrm{Q} 14)$ and $1.5(\mathrm{Q} 5)$. The average values of $\mathrm{I}_{\gamma}$ are below the criterion of 2 corresponding to the annual effective dose $0.3 \mathrm{mSv}$ for ornamental applications, except for Q13. However, the average values of $\mathrm{I}_{\gamma}$ estimated for the samples from Q5, Q12, Q13, Q14 and Q16 are above the criterion of unity corresponding to the annual effective dose $1 \mathrm{mSv}$ for structural applications.

\subsubsection{Alpha index}

A few internal indices dealing with the evaluation of the excess alpha radiation due to inhalation originating from 
building materials were developed (Righi and Bruzzi, 2006). In this study, the alpha index $\left(\mathrm{I}_{\alpha}\right)$ as an internal index was estimated by the following formula:

$$
\mathrm{I}_{\alpha}=\frac{\mathrm{A}_{\mathrm{Ra}}}{200 \mathrm{~Bq} \mathrm{~kg}^{-1}}
$$

where $\mathrm{A}_{\mathrm{Ra}}$ is the activity concentration of ${ }^{226} \mathrm{Ra}$ in $\mathrm{Bq} \mathrm{kg}^{-1}$. $\mathrm{I}_{\alpha} \leqslant 1$ corresponds to a ${ }^{226} \mathrm{Ra}$ activity concentration less than or equal to $200 \mathrm{~Bq} \mathrm{~kg}^{-1}$. When the activity concentration of ${ }^{226} \mathrm{Ra}$ in a building material exceeds the value of $200 \mathrm{~Bq} \mathrm{~kg}^{-1}$, it is possible that the radon exhalation from this material could cause an indoor radon concentration exceeding the recommended upper level of $200 \mathrm{~Bq} \mathrm{~m}^{-3}$ (Righi and Bruzzi, 2006). Recently, the WHO recommended a reference level of $100 \mathrm{~Bq} \mathrm{~m}^{-3}$ to minimize health hazards caused by indoor radon exposure (WHO, 2009). In this case, $\mathrm{I}_{\alpha} \leqslant 0.5$ corresponds to a ${ }^{226} \mathrm{Ra}$ activity concentration less than or equal to $100 \mathrm{~Bq} \mathrm{~kg}{ }^{-1}$. The estimated $\mathrm{I}_{\alpha}$ for all volcanic tuff samples ranged from 0.01 to 1.31 with an average of $0.31 \pm 0.03$. The average values of $\mathrm{I}_{\alpha}$ are given in the third column of Table 5 . It can be seen in Table 5 that all values of $\mathrm{I}_{\alpha}$ are below the recommended upper level of unity. Also, all values of $\mathrm{I}_{\alpha}$ are below the reference level recommended by the WHO, except for Q13 and Q14.

\subsubsection{Estimation of the absorbed indoor gamma dose rate and the annual effective dose}

Volcanic tuff stones are used for wall masonry and/or internal partition walls in construction of dwellings in the Cappadocia region of Turkey due to their aesthetic appearance and performance characteristics such as good heat insulation. The indoor absorbed dose rate $\left(D_{\text {in }}\right)$ and annual effective dose $\left(E_{\text {in }}\right)$ due to gamma-ray emission from the radionuclides in the volcanic tuff samples were evaluated using the data and formula provided by EC reports (EC, 1999). In the EC reports, the dose conversion coefficients were calculated for the standard room center. The dimensions of the room are $4 \mathrm{~m} \times 5 \mathrm{~m} \times 2.8 \mathrm{~m}$. The thickness of the walls, floor and ceiling, and density of the structures are $20 \mathrm{~cm}$ and $2350 \mathrm{~kg} \mathrm{~m}^{-3}$ (concrete), respectively. These coefficients correspond to $0.92 \mathrm{nGy} \mathrm{h}^{-1}$ per Bq kg${ }^{-1}$ for ${ }^{226} \mathrm{Ra}, 1.1 \mathrm{nGy} \mathrm{h}^{-1}$ per Bq kg${ }^{-1}$ for ${ }^{232} \mathrm{Th}$ and $0.080 \mathrm{nGy} \mathrm{h}{ }^{-1}$ per $\mathrm{Bq} \mathrm{kg}^{-1}$ for ${ }^{40} \mathrm{~K}$.

$$
\mathrm{D}_{\text {in }}\left(\mathrm{nGy} \mathrm{h}^{-1}\right)=0.92 \times \mathrm{A}_{\mathrm{Ra}}+1.1 \times \mathrm{A}_{\mathrm{Th}}+0.080 \times \mathrm{A}_{\mathrm{K}}
$$

where $A_{R a}, A_{T h}$ and $A_{K}$ are the specific activities of ${ }^{226} \mathrm{Ra}$, ${ }^{232} \mathrm{Th}$ and ${ }^{40} \mathrm{~K}$ in $\mathrm{Bq} \mathrm{kg}{ }^{-1}$, respectively. The conversion factor from the absorbed dose in air to the effective dose and the indoor occupancy factor has to be taken into account in order to estimate the corresponding annual effective dose. In the UNSCEAR (1982) and EC (1999) reports, a value of 0.7 Sv Gy ${ }^{-1}$ was used for the conversion factor from the absorbed dose in air to the effective dose received by adults, and 0.8 for the indoor occupancy factor, implying that $80 \%$ of time is spent indoors, on average, around the world (UNSCEAR, 1982). The annual effective dose $\left(E_{\text {in }}\right)$ was estimated as follows:

$$
\mathrm{E}_{\text {in }}(\mathrm{mSv})=\mathrm{D}_{\text {in }} \times 8766 \mathrm{~h} \times 0.8 \times 0.7 \mathrm{~Sv} \mathrm{~Gy}^{-1} \times 10^{-6}
$$

where $D_{\text {in }}\left(n G y h^{-1}\right)$ is given by equation (8).
The estimated $\mathrm{D}_{\text {in }}$ values for all the volcanic tuff stone samples used as structural building materials ranged from 19 to $799 \mathrm{nGy} \mathrm{h}^{-1}$ with an average of $221 \pm 20 \mathrm{nGy} \mathrm{h}^{-1}$. The average values of $D_{\text {in }}$ are given in the fourth column of Table 5 . When the average value of $50 \mathrm{nGy} \mathrm{h}^{-1}$ for the background is subtracted from the average value of $D_{\text {in }}$, the remaining value of $D_{\text {in }}$ is 2 times higher than the world average (populationweighted) indoor absorbed gamma dose rate of $84 \mathrm{nGy} \mathrm{h}^{-1}$ (UNSCEAR, 2008). It can be seen in Table 5 that the average values of $D_{\text {in }}$ are higher than the quoted world average value, except for Q7, Q15 and Q17. The average value of $\mathrm{D}_{\text {in }}$ is about 3 times higher than the quoted world average value.

The estimated $\mathrm{E}_{\mathrm{in}}$ values ranged from 0.1 to $3.9 \mathrm{mSv}$ with an average of $1.1 \pm 0.1 \mathrm{mSv}$. The average values of $\mathrm{E}_{\text {in }}$ are given in the fifth column of Table 5 . It can be seen in Table 5 that the average values of $\mathrm{E}_{\text {in }}$ are lower than the dose limit value of 1, except for Q5 (1.8 mSv), Q12 (1.4 mSv), Q13 (3.3 $\mathrm{mSv}), \mathrm{Q} 14(1.9 \mathrm{mSv})$ and Q16 (1.2 mSv). The average value of $\mathrm{E}_{\mathrm{in}}$ is slightly higher than the quoted dose limit.

\section{Conclusions}

Radiometric analysis of 76 samples of volcanic tuff stones collected from different quarries located in Central Anatolia, Eastern Anatolia, and Mediterranean and Aegean regions in Turkey were performed using a gamma-ray spectrometer with a HPGe detector. The average activity concentrations of ${ }^{238} \mathrm{U}$, ${ }^{232} \mathrm{Th},{ }^{226} \mathrm{Ra}$ and ${ }^{40} \mathrm{~K}$ were measured as 94, 104, 62 and $623 \mathrm{~Bq} \mathrm{~kg}{ }^{-1}$, respectively. Also, the average values of the emanation coefficient and the ${ }^{222} \mathrm{Rn}$ mass exhalation rate of the volcanic tuff samples were found to be $68 \%$ and $43 \pm$ $5 \mu \mathrm{Bq} \mathrm{kg} \mathrm{k}^{-1} \mathrm{~s}^{-1}$, respectively. The volcanic tuff samples show average concentration values that are significantly higher than the earth's crust averages.

For each sample in this study, the gamma index, alpha index, absorbed gamma dose rate in indoor air and the corresponding annual effective dose were estimated to evaluate the radiological risks. The results revealed that the radiological hazard indices estimated for all surveyed volcanic tuff stone samples do not exceed the recommended upper limit values when used as covering building materials for ornamental or insulating covering purposes. However, the Q5, Q12, Q13, Q14 and Q16 volcanic tuff samples collected from quarries could cause significant exposure to gamma radiation when used as structural materials. Therefore, the use of these volcanic tuff stone samples as structural building materials should be restricted. In case of the use of these volcanic tuff stone samples, appropriate measures such as ventilation are required.

Acknowledgements. This study was carried out within the framework of a master thesis conducted at Nevşehir Haci Bektaş Veli University and Research Project 114Y042 supported by The Scientific and Technological Research Council of Turkey (TÜBİTAK). The authors would like to thank the Turkish Atomic Energy Authority (TAEK) and TÜBİTAK. 


\section{References}

Abd El-Ghafour N.G., Khalil M.H., Gharib M.E., Abd Latif M.L. (2012) Mineralogical and radioactive properties of some Egyptian granitoid rocks and their suitability for ornamental stones, HBRC J. 8, 64-68.

Anjos R.M., Veiga R., Soares T., Santos A.M.A., Aguiar J.G., Frascá M.H.B.O., Brage J.A.P., Uzêda D., Mangia L., Facure A., Mosquera B., Carvalho C., Gomes P.R.S. (2005) Natural radionuclide distribution in Brazilian commercial granites, Radiat. Meas. 39, 245-253.

Asghar M., Tufail M., Sabiha-Javied Abid A., Waqas M. (2008) Radiological implications of granite of northern Pakistan, J. Radiol. Prot. 28, 387-399.

Capaccioni B., Cinelli G., Mostacci D., Tositti L. (2012) Longterm risk in a recently active volcanic system: Evaluation of doses and indoor radiological risk in the quaternary Vulsini Volcanic District (Central Italy), J. Volc. Geotherm. Res. 247-248, 26-36.

Chowdhury I.M., Alam M.N., Ahmed A.K.S. (1998) Concentration of radionuclides in building and ceramic materials of Bangladesh and evaluation of radiation hazard, J. Radioanal. Nucl. Chem. 231 (1-2), 117-122.

Currie L.A. (1968) Limits for qualitative detection and quantitative determination, Anal. Chem. 40, 586-593.

Değerlier M. (2013) Assessment of natural radioactivity and radiation hazard in volcanic tuff stones used as building and decoration materials in the Cappadocia region, Turkey, Radioprotection 48 (2), 215-219.

EC (European Commission) (1999) Radiation protection 112Radiological protection principles concerning the natural radioactivity of building materials. Directorate- General Environment, Nuclear Safety and Civil Protection.

El-Arabi A.M. (2007) ${ }^{226} \mathrm{Ra},{ }^{232} \mathrm{Th}$ and ${ }^{40} \mathrm{~K}$ concentration in igneous rocks from eastern desert, Egypt and its radiological implication, Radiat. Meas. 42, 94-100.

Kitto M.E., Haines D.K., Menia T.A. (2009) Assessment of gammaray emissions from natural and manmade decorative stones, $J$. Radioanal. Nucl. Chem. 282, 490-413.

Koornneef J.M., Stracke A., Aciego S., Reubi O., Bourdon B. (2010) A new method for U-Th-Pa-Ra separation and accurate measurement of ${ }^{234} \mathrm{U}-{ }^{230} \mathrm{Th}-{ }^{231} \mathrm{~Pa}-{ }^{226} \mathrm{Ra}$ disequilibria in volcanic rocks by MC-ICPMS, Chem. Geo. 277, 30-41.
Lanzo G., Basile S., Brai M., Rizzo S. (2010) Volcanic products of Lipari (Aeolian islands, Italy): Multivariate analysis of petrographic and radiometric data, Radiat. Meas. 45, 816-822.

Lavi N., Groppi F., Alfassi Z.B. (2004) On the measurement of ${ }^{40} \mathrm{~K}$ in natural and synthetic materials by the method of high-resolution gamma ray spectrometry, Radiat. Meas. 38, 139-143.

Marocchi M., Righi S., Bargossi G.M., Gasparotto G. (2011) Natural radionuclides content and radiological hazard of commercial ornamental stones: An integrated radiometric and mineralogicalpetrographic study, Radiat. Meas. 46, 538-545.

Moura C.L., Artur A.C., Bonotto D.M., Guedes S., Martinelli C.D. (2011) Natural radioactivity and radon exhalation rate in Brazilian igneous rocks, Appl. Radiat. Isotopes 69, 1094-1099.

Righi S., Bruzzi L. (2006) Natural radioactivity and radon exhalation in building materials used in Italian dwellings, J. Environ. Radioact. 88, 158-170.

Trevisi R., Risica S., D’Alessandro M., Paradiso D., Nuccetelli C. (2012) Natural radioactivity in building materials in the European Union: a database and an estimate of radiological significance, J. Environ. Radioact. 105, 11-20.

Turhan Ş., Gündüz L. (2008) Determination of specific activity of ${ }^{226} \mathrm{Ra},{ }^{232} \mathrm{Th}$ and ${ }^{40} \mathrm{~K}$ for assessment of radiation hazards from Turkish pumice samples, J. Environ. Radioact. 99-2, 332-342.

Turhan Ş. (2009) Radiological impacts of the usability of clay and kaolin as raw material in manufacturing of structural building materials in Turkey, J. Radiol. Prot. 29, 75-83.

Turhan Ş. (2012) Estimation of possible radiological hazards from natural radioactivity in commercially-utilized ornamental and countertops granite tiles, Ann. Nucl. Energy 44, 34-39.

UNSCEAR (1982) Ionizing radiation: Sources and biological effects. United Nations Scientific Committee on the Effects of Atomic Radiation, United Nations Publication, New York, USA.

UNSCEAR (2008) Sources and effects of ionizing radiation. United Nations Scientific Committee on the Effects of Atomic Radiation, United Nations Publication, New York, USA.

White G.J., Rood A.S. (2001) Radon emanation from NORMcontaminated pipe scale and soil at petroleum industry sites, J. Environ. Radioact. 54, 401-413.

WHO (2009) Handbook on indoor radon. A public health perspective. WHO Library Cataloguing-in-Publication Data NLM classification: WN 615, France.

Xinwei L., Lingqing W., Xiaodan J. (2006) Radiometric analysis of Chinese commercial granites, J. Radioanal. Nucl. Chem. 267 (3), 669-673.

Cite this article as: Ş. Turhan, E. Atıcı, A. Varinlioğlu. Radiometric analysis of volcanic tuff stones used as ornamental and structural building materials in Turkey and evaluation of radiological risk. Radioprotection 50(4), 273-280 (2015). 